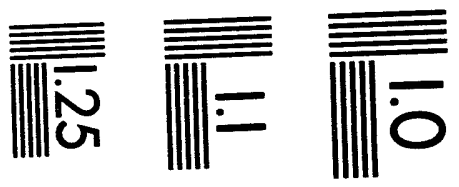

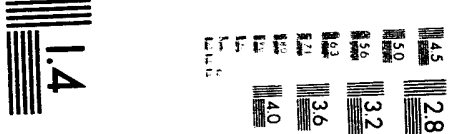

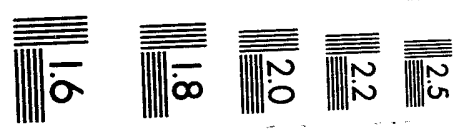



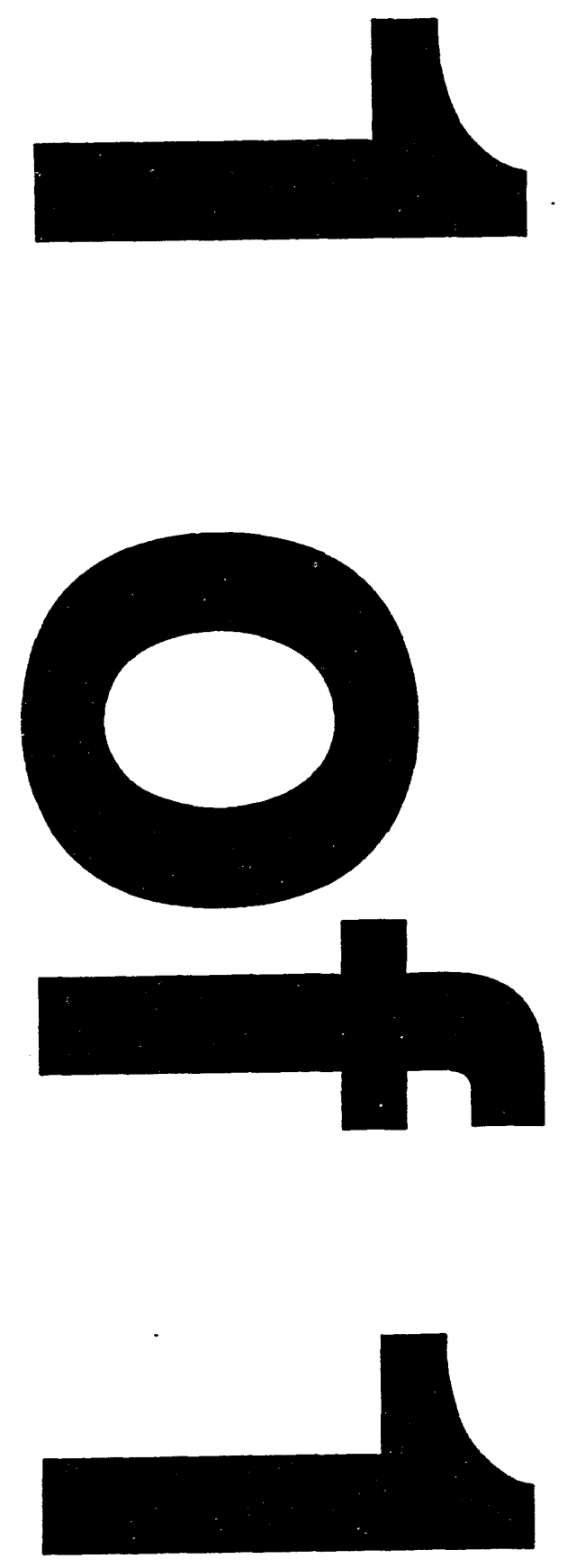


\title{
Conf $-931201--9$
}

\author{
SAND93-3846C \\ LBL-34896 \\ LONG TeRm PlutoniUm SOlubility AND SPECIATION STUdieS \\ IN A SYNTHETIC BRINE
}

Heino Nitsche, Kevin Roberts, Ruihua Xi, Traudel Prussin, Kevin Becraft, Ilham Al Mahamid Al Rifai, Herbert B. Silber, Scott A. Carpenter, Raymond C. Gatti

Earth Sciences Division, Lawrence Berkeley Laboratory, Berkeley, California 94720 USA

\section{Craig F. Novak}

Mail Stop 1320, Department 6119, Sandia National Laboratories, Albuquerque, New Mexico 87185-1320 USA

Keywords: Plutonium/Solubility/Speciation/Waste Isolation Pilot Plant (WIPP)/Brine

\section{Abstract}

The rate at which elements can be transported in groundwater systems is governed in part by the solubility of the element in the groundwater. This report documents plutonium solubility experiments, conducted over the past two years at the Lawrence Berkeley Laboratory, in a brine simulant relevant to the Waste Isolation Pilot Plant. Approximately 1 to $2.5 \mathrm{~mL}$ of five stock solutions containing single oxidation states of plutonium ( $\mathrm{Pu}(\mathrm{IV})$-polymer, $\mathrm{Pu}^{3+}, \mathrm{Pu}^{4+}, \mathrm{PuO}_{2}^{+}$, and $\mathrm{PuO}_{2}^{2+}$ ) were added to $\sim 75 \mathrm{~mL}$ of synthetic $\mathrm{H}-17$ Brine in five reaction vessels. Initial plutonium concentrations ranged from $1.3 \times 10^{-4}$ to $5.1 \times 10^{-4} \mathrm{M}$ (moles per liter) total plutonium. Because these initial concentrations were far above the plutonium solubility limit in H-17 Brine, plutonium-containing solids precipitated. Aqueous plutonium concentrations were measured over time until steady-state was reached, requiring over 300 days in $\mathrm{H}-17$ Brine. Steady-state plutonium concentrations ranged from $3.0 \times 10^{-8}$ to $7.6 \times 10^{-7} \mathrm{M}$, and the predominant plutonium oxidation state in solution was $\mathrm{Pu}(\mathrm{VI})$. The solid phase from the initially $\mathrm{Pu}(\mathrm{IV})$ polymer experiment remained polymeric-Pu(IV). The solids that formed in the initially $\mathrm{Pu}^{3+}$ and $\mathrm{Pu}^{4+}$ experiments were crystalline yet remain unidentified. The solids that formed in the initially $\mathrm{PuO}_{2}^{+}$and $\mathrm{PuO}_{2}^{2+}$ experiments appear to be sodium plutonyl $(\mathrm{V})$ carbonates. 


\section{Introduction}

Understanding the behavior of dissolved plutonium in natural systems is important for assessing the performance of proposed nuclear waste repositories. Migration of dissolved plutonium depends upon the plutonium oxidation state and concentrations of groundwater constituents that can complex with the plutonium. In addition, the total dissolved plutonium concentration depends on the plutoniumbearing solid phase(s) that control solubility. Particularly for plutonium in brine systems, little experimental data exists for demonstrating either oxidation states or the solubility-controlling solids. This paper documents steady-state plutonium concentrations, oxidation state distributions, and solubility-controlling solids in a complex synthetic groundwater.

This solubility study was undertaken in support of the Waste Isolation Pilot Plant (WIPP), a U.S. Department of Energy facility intended to demonstrate the safe geologic disposal of defense-generated transuranic nuclear waste. The WIPP is located deep underground in a bedded salt formation in southeastern New Mexico. The little groundwater that exists in the WIPP vicinity range from seawater-like ( $\sim 0.8$ molal ionic strength) brines to highly concentrated ( $\sim 8$ molal) brines. 1 The chemical behavior of actinides in a variety of groundwaters from near the WIPP Site is being examined to support WIPP solubility and retardation studies.

This paper documents solubility studies of ${ }^{239} \mathrm{Pu}$ in $\mathrm{H}-17$ Brine, a simulant of brine taken from near the W!IPP Site. Plutonium in five different initial forms ( $\mathrm{Pu}(\mathrm{IV})$-polymer, $\mathrm{Pu}^{3+}, \mathrm{Pu}^{4+}, \mathrm{PuO}_{2}^{+}$, and $\mathrm{PuO}_{2}^{2+}$ ), was added to the brine in five separate reaction vessels, in sufficient quantity to ensure initial supersaturation with $\mathrm{Pu}$. The experiments were conducted under oxic conditions with a fixed carbon dioxide overpressure, and the nominal hydrogen ion concentration was controlled over the length of the experiments. Total dissolved concentrations of plutonium were monitored over time until steady-state conditions were established. Aqueous 
plutonium oxidation state distributions were determined several times during the experiments, and the solid phases were characterized.

\section{Experimental}

Reagent grade chemicals were used to make synthetic $\mathrm{H}-17$ Brine, with the composition as listed in Table 1 . The anhydrous salts were dried in an oven at $110^{\circ} \mathrm{C}$ for four hours before use. Salts were massed on a Galaxy 400 analytical balance that had been calibrated using an NIST standardized mass set. All salts except sodium bicarbonate were added to a $1 \mathrm{~L}$ class " $\mathrm{A}$ " volumetric flask, the flask was flushed with argon for 10 minutes, and freshly distilled, deionized water was added. All solids dissolved with stirring over night. The $\mathrm{NaHCO}_{3}$ was added immediately before saturating the water simulant with the $\mathrm{CO}_{2} / \mathrm{O}_{2} / \mathrm{Ar}$ gas mixture.

Because the concentration of total inorganic carbon (TIC) in solution can change in response to the carbon dioxide content of gas over the solution, special care was taken to preserve the intended TIC concentration of $\mathrm{H}-17$ Brine. This was accomplished by equilibrating the solutions with gas mixtures of (2634 \pm 91$) \mathrm{ppm}$ $\mathrm{CO}_{2}$. The gas mixtures also contained $(20.75 \pm 0.88) \%$ oxygen to provide an oxic environment, with the balance made up of argon.

We measured the brine $\mathrm{pH}$ during saturation with carbon dioxide with a Ross glass combination $\mathrm{pH}$ electrode (Orion Research Incorporated, Boston, MA) to establish an operational $\mathrm{pH}$ that could be routinely measured with a glass electrode. This is not the actual $\mathrm{p}\left[\mathrm{H}^{+}\right]$, or $\mathrm{pcH}$, of the brine, but rather an operational $\mathrm{pH}_{\mathrm{OP}}$ that we maintained during the solubility experiments. The electrode was calibrated with NIST traceable standard buffers of 7 and 10 before being placed into the H-17 Brine. Figure 1 shows the change in the measured $\mathrm{pH}_{\mathrm{OP}}$ during the saturation with the $\mathrm{CO}_{2} / \mathrm{O}_{2} / \mathrm{Ar}$ gas mixture. After eight hours of saturation with the gas mixture, the initial $\mathrm{pH}_{\mathrm{OP}}$ of 8.06 stabilized to $\mathrm{pH}_{\mathrm{OP}}=7.14$.

The ${ }^{239} \mathrm{Pu}$ stock solution was prepared by dissolving plutonium metal in $6 \mathrm{M}$ 
hydrochloric acid. The solution was purified from possible metal contaminants by anion exchange chromatography. The oxidation states $\mathrm{Pu}(\mathrm{III}), \mathrm{Pu}(\mathrm{IV}), \mathrm{Pu}(\mathrm{V})$, and $\mathrm{Pu}(\mathrm{VI})$ were prepared by electrochemical adjustment of the plutonium stock solution. ${ }^{2-3}$ The presence of a single oxidation state was verified by absorption spectrophotometry. 4 Before use, all stock solutions were filtered through $0.22 \mu \mathrm{m}$ polyvinylidene difluoride syringe filter units (Millipore Corporation, Bedford, MA) to remove possible suspended particles (e.g., dust or silica) that could sorb the plutonium to form pseudocolloids.

The $\mathrm{Pu}(\mathrm{IV})$-polymer was prepared by oxidizing a $\mathrm{Pu}(\mathrm{III})$ stock solution, $(\mathrm{pH}=2.5)$, at +1.1 volts versus a normal hydrogen electrode to $\mathrm{Pu}(\mathrm{IV})$ that immediately polymerized and settled out of solution.

The equilibration vessels were $90 \mathrm{~mL}$ Teflon perfluoralkoxy (PFA) cells (Savillex Corporation, Minnetonka, MN) with ports at the top to accommodate a pH electrode, a 1/16"-diameter Teflon line for the gas mixture, and an opening for withdrawing samples. Five individual reaction vessels were prepared to accommodate the five forms of plutonium stock solution to be studied.

Approximately 1 to $2.5 \mathrm{~mL}$ of each plutonium stock solution were added to 70 $\mathrm{mL} \mathrm{H}-17$ at the start of the experiment. The $\mathrm{pH}_{\mathrm{OP}}$ of the solutions was measured weekly and maintained at $7.14 \pm 0.10$. When required, the $\mathrm{pH}_{\mathrm{OP}}$ in the reaction vessels was adjusted with small amounts (usually between 5 and $50 \mu \mathrm{L}$ ) of $\mathrm{HCl}$ or $\mathrm{NaOH}$ (0.5-1 M). The electrodes were removed from the plutonium solutions after each $\mathrm{pH}_{\mathrm{OP}}$ measurement.

Quantitative separation of the aqueous phase from any solids or suspended particles is necessary for an accurate assessment of dissolved concentrations. For this process, we routinely used Centricon-30 (Amicon Corporation, Danvers, MA) centrifugal filters that contain a YM-type membrane with a calculated pore size of $4.1 \mathrm{~nm}$. Filters were tested for plutonium retention by filtering $500 \mu \mathrm{L}$ of the 
solubility solution and counting the filtrate. Another $500 \mu \mathrm{L}$ of solution was filtered through the same filter, and the second filtrate was assayed. This was repeated until a total volume of $2000 \mu \mathrm{L}$ had passed through the filter. Plutonium retention would be indicated by an increase in assayed concentration with each successive filtration step. Figure 2 shows that the filters did not retain the dissolved plutonium species present at the initiation of the five solubility experiments. Because plutonium concentrations and speciation may change over the course of the experiment, another test for filter retention was performed after $\sim 150$ days of reaction time, and again the results showed no significant retention of plutonium. Routine separations were performed after presaturating the filters with $500 \mu \mathrm{L}$ of solution.

Concentration measurements of the aqueous portions were made by $\gamma$-spectroscopy with a low-energy germanium counting system of Lawrence Berkeley Laboratory design, or with a liquid scintillation counter (Pharmacia LKB Nuclear Incorporated, Gaithersburg, MD, Model Rackbeta 1219). With the germanium counter, plutonium was analyzed for the uranium $L$ x-rays resulting from the $\alpha$-decay of the plutonium. Possible contributions to the $L \mathrm{x}$-rays from the decays of other radionuclides, also present in small amounts, were corrected by subtraction. 5 The liquid scintillation counter (LSC) can discriminate between possible $\beta$-radiation and the plutonium $\alpha$-radiation. The LSC was calibrated with plutonium standards of similar chemical compositions.

The oxidation state of plutonium is one of the most important controlling factors for solubility. Although each experiment started with a single oxidation state, the oxidation states can and, in general, do change during solubility experiments. Unfortunately, the steady-state plutonium concentrations in H-17 Brine were below the detection limit of conventional methods such as absorption spectrophotometry, so a series of organic extractions was used as an indirect method 
for determining the distribution of the aqueous plutonium among its oxidation states. Table 3 lists the methods that we used. The method is based upon an earlier scheme, 6 but for these solubility experiments we replaced thenoyltrifluoroacetone (TTA) with 1-phenyl-3-methyl-4-benzoy-pyrazol-5-one (PMBP) 7 because PMBP was more efficient as an extractant and was more resistant to decomposition by oxidants such as dichromate. All extractions were successfully tested on known oxidation states of plutonium in H-17 Brine. For the solubility experiments, each of the four separations was carried out independently to minimize the potential for changing the steady state distribution.

The oxidation potential, Eh, of each solution was measured at steady state with a platinum electrode versus a $\mathrm{Ag} / \mathrm{AgCl} / \mathrm{saturated} \mathrm{NaCl}$ reference. The platinum electrode was cleaned with $6 \mathrm{M}$ nitric acid before and after each measurement. The electrode setup was checked with "Zobell's Solution" before and after each measurement. $8-9$

The solids were analyzed by $\mathrm{x}$-ray powder diffraction. A few micrograms of each actinide precipitate were placed in a $0.33-\mathrm{mm}$ diameter quartz capillary tube. The tube was mounted in an $11.46-\mathrm{cm}$ diameter Debye-Scherrer camera and then irradiated with x-rays from a Norelco III x-ray generator (Philips Electronics, Inc.). Copper $\mathrm{K}_{\alpha}$ radiation filtered through nickel was used.

\section{Results and Discussion}

\section{Solubility}

The experimental results for dissolved plutonium concentrations are shown in Figure 3. The steady-state $\mathrm{pH}$ values, plutonium concentrations, and Eh values are given in Table 2.

The dissolved concentrations in the initially $\mathrm{Pu}(\mathrm{III}), \mathrm{Pu}(\mathrm{IV}), \mathrm{Pu}(\mathrm{V})$, and $\mathrm{Pu}(\mathrm{IV})$-polymer experiments dropped by two to three orders of magnitude within about 50 days. After that time, the concentrations changed no more than an order 
of magnitude over 600 additional days. The initially $\mathrm{Pu}(\mathrm{VI})$ experiment behaved very differently, remaining significantly higher in its aqueous plutonium concentration for about 250 days before a similar drop in aqueous plutonium occurred. After approximately 350 days of reaction time, the concentrations for the initially $\mathrm{Pu}(\mathrm{III}),(\mathrm{IV}),(\mathrm{V})$, and (VI) experiments were all within a factor of 1.6 of one another, their average being $\sim 5 \times 10^{-7} \mathrm{M}$. The plutonium concentration in the initially $\mathrm{Pu}(\mathrm{IV})$-polymer experiment was an order of magnitude lower, $4.3 \times 10^{-8} \mathrm{M}$. Note that true steady state conditions in H-17 Brine were not reached even after nearly 700 days of equilibration time.

Steady-state concentrations listed in Table 2 are the averages of the individual concentration measurements from days 279 to 668 for the initially $\mathrm{Pu}(\mathrm{IV})$-polymer experiment, from 419 to 680 for the initially $\mathrm{Pu}(\mathrm{III})$ experiment, from 413 to 674 for the initially $\mathrm{Pu}(\mathrm{IV})$ experiment, from 290 to 679 for the initially $\mathrm{Pu}(\mathrm{V})$ experiment, and from 252 to 680 for the initially $\mathrm{Pu}(\mathrm{VI})$ experiment. The error listed with each average concentration is the standard deviation.

The five H-17 experiments were oxic, with measured Eh values from 400 to $500 \mathrm{mV}$ versus a normal hydrogen electrode. These measurements are very general and are of limited value because they represent a combination of many redox reactions in each of these solubility experiments. Only with elaborate chemical modeling can these overall potentials be explained.

\section{Oxidation State Determinations}

Results of oxidation state determinations performed at steady state in the solubility experiments are shown in Figure 4. These determinations were performed after approximately 350 days of reaction time and after steady-state conditions were met. The results show $\mathrm{Pu}(\mathrm{VI})$ as the predominant oxidation state in solution at steady state regardless of the oxidation state used at the start of the experiments. We also found smaller, but significant, amounts of $\mathrm{Pu}(\mathrm{V})$ in some of 
the solutions. These observed valence distributions cannot be explained by disproportionation equilibria and complex stabilization. ${ }^{10}$ It is possible that reaction products formed by $\alpha$-radiolysis of $\mathrm{H}-17$ Brine may cause the predominance of high oxidation states in the plutonium solutions. We confirmed the oxidation state results shown in Figure 4 later in the experiments, using the same separation scheme.

\section{Identification And Characterization Of Solids}

The solids formed in the H-17 oversaturation experiments were examined after approximately 600 days of reaction time. From visual observations, it appeared that the solids formed in the initially $\mathrm{Pu}$ (IV)-polymer, $\mathrm{Pu}$ (III), and $\mathrm{Pu}$ (IV) experiments were very much the same. They each resembled the green polymericplutonium(IV) used to start the initially $\mathrm{Pu}(\mathrm{IV})$-polymer solubility experiment. The crystalline component in the solids that formed in the initially $\mathrm{Pu}(\mathrm{V})$ and $\mathrm{Pu}(\mathrm{VI})$ experiments also appeared to be the same; they were both a tan, crystalline powder.

To determine if the green solids we obtained were polymeric-plutonium(IV), we tried dissolving very small portions of the solids in $1 \mathrm{M} \mathrm{HCl}$. We then filtered the solutions through Amicon Centriprep-30 centrifugal filters $(4.1 \mathrm{~nm})$. We assayed the acidified plutonium solutions before and after filtration to determine the relative amount of solid that dissolved in $1 \mathrm{M} \mathrm{HCl}$. Crystalline solids like plutonium hydroxides or plutonium carbonates will immediately dissolve in $1 \mathrm{M}$ $\mathrm{HCl}$; whereas, polymeric-plutonium(IV) will not dissolve. The filtration will remove any undissolved solids larger than $4.1 \mathrm{~nm}$ from the solution. We expected that for the initially $\mathrm{Pu}(\mathrm{IV})$-polymer experiment, very little solid, if any, would dissolve and/or pass through the filter. Only 14 percent of the acidified plutonium solid passed through the filter. This may have been a crystalline component or possibly carbonate complexed plutonium on the surface of the polymeric-plutonium(IV) that did dissolve. It also may have been polymeric-plutonium(IV) that was smaller than 
$4.1 \mathrm{~nm}$ and passed through the filter without dissolving. In either case, eighty-six percent of the solid did not dissolve and is most likely $\mathrm{Pu}(\mathrm{IV})$-polymer.

For the initially $\mathrm{Pu}(\mathrm{III})$ and $\mathrm{Pu}(\mathrm{IV})$ experiments, 76 and 73 percent of the respective solids dissolved and/or passed through the filter. These results show that approximately three quarters of the plutonium solids that formed in these two experiments may not be polymeric-plutonium(IV). If this component has a higher solubility than polymeric-plutonium(IV), it would explain why the steady-state aqueous plutonium concentrations in the initially $\mathrm{Pu}(\mathrm{III})$ and $\mathrm{Pu}(\mathrm{IV})$ experiments are an order of magnitude higher than that found in the initially $\mathrm{Pu}(\mathrm{IV})$-polymer experiment.

Ninety-three and 100 percent of the respective solids from the initially $\mathrm{Pu}(\mathrm{V})$ and $\overline{F u}(\mathrm{VI})$ experiments dissolved and/or passed through the filters. These solids are believed to have dissolved because they effervesced upon contact with acid. This also implies that these plutonium solids contained carbonate. The seven percent of the solid from the initially $\mathrm{Pu}(\mathrm{V})$ experiment that did not dissolve or pass through the filter is probably polymeric-plutonium(IV), which explains the small amount of the green solid we found with the crystalline component.

To further characterize these plutonium solids, we isolated small portions of the plutonium solids for x-ray powder diffraction. Microgram amounts of the dried plutonium solids were encapsulated in quartz capillaries and then analyzed by $\mathbf{x}-\mathrm{ray}$ powder diffraction. The d-spacings and relative intensities for the powder patterns of the dried plutonium solids are listed in Table 4. We also washed another portion of the solids with distilled water followed by ethanol to try removing any salts, such as $\mathrm{NaCl}$, that may have coprecipitated from the brine. Although washing may perturb the crystal structure of the plutonium solids, the respective powder patterns show little change between washed and unwashed samples.

We compared the $\mathrm{x}$-ray powder diffraction patterns with reference patterns 
published in the literature to assign the lines. They were compared to patterns of crystalline $\mathrm{PuO}_{2},{ }^{11} \mathrm{PuO}_{3} \bullet 0.8 \mathrm{H}_{2} \mathrm{O}, 12 \mathrm{KPuO}_{2} \mathrm{CO}_{3},{ }^{13} \quad \mathrm{NH}_{4} \mathrm{PuO}_{2} \mathrm{CO}_{3},{ }^{13}$ and $\mathrm{PuO}_{2} \mathrm{CO}_{3} .{ }^{14}$

The three solids from the initially $\mathrm{Pu}(\mathrm{IV})$-polymer, $\mathrm{Pu}$ (III), and $\mathrm{Pu}(\mathrm{IV})$ dissolved concentration experiments in H-17 Brine produced powder patterns with the same diffraction lines. Because very little of the solid produced in the initially $\mathrm{Pu}(\mathrm{IV})$-polymer experiment dissolved in acid, we conclude that the solid taken from the end of the experiment was composed mostly of $\mathrm{Pu}(\mathrm{IV})$-polymer. However, most of the solids produced in the initially $\mathrm{Pu}$ (III) and $\mathrm{Pu}(\mathrm{IV})$ experiments did dissolve in $1 \mathrm{M} \mathrm{HCl}$ and/or pass through the filter, so we conclude that these solid phases are possibly crystalline or $\mathrm{Pu}(\mathrm{IV})$-polymer smaller than $4.1 \mathrm{~nm}$. The $\mathrm{x}$-ray powder diffraction patterns did not match any of the published reference patterns for plutonium compounds. We indexed the d-spacings to determine the lattice structure and found that a cubic lattice structure, like that of sodium chloride, for example, will produce these diffraction lines.

The crystalline precipitates from the $\mathrm{H}-17$ Brine experiments containing initially $\mathrm{PuO}_{2}^{+}$and $\mathrm{PuO}_{2}^{2+}$ had identical x-ray powder diffraction patterns, and this pattern compared well with patterns of $\mathrm{KPuO}_{2} \mathrm{CO}_{3}{ }^{13}$ and $\mathrm{NH}_{4} \mathrm{PuO}_{2} \mathrm{CO}_{3} .13$ However, considering that the sodium content in H-17 Brine is nearly 80 times greater than the potassium content, we conclude that these solids are more likely sodium plutonyl(V) carbonates, $\mathrm{NaPuO}_{2} \mathrm{CO}_{3}(\mathrm{~s})$. No reference powder pattern was found for $\mathrm{NaPuO}_{2} \mathrm{CO}_{3}(\mathrm{~s})$, but the $\mathrm{NaPuO}_{2} \mathrm{CO}_{3}$ unit cell lattice structure was reported in comparison with the analogous potassium and ammonium solids. ${ }^{15}$ Precipitation of plutonyl(V) with carbonate results in hexagonal, orthorhombic, or monoclinic solids depending on the size of the accompanying cation involved. Larger accompanying cations, like ammonium, favor the formation of a hexagonal crystal lattice. The potassium cation forms an orthorhombic solid; whereas, the 
smaller alkali cation, sodium, precipitates the plutonyl(V) carbonate as a monoclinic solid. We indexed the powder pattern from the solid obtained in the initially $\mathrm{Pu}(\mathrm{V})$ and $\mathrm{Pu}(\mathrm{VI})$ oversaturation experiments with hexagonal, orthorhombic, and monoclinic crystal lattices. Only a monoclinic crystal lattice was able to produce calculated d-spacings that agreed with the experimental powder patterns.

\section{Conclusions}

These studies demonstrate a successful methodology for accurately determining the solubility or dissolved concentrations of plutonium in brines. The measurement of dissolved concentrations in solubility studies is obviously not a "quick and dirty" process. The experiments documented here required on the order of three to four months to reach an approximate steady state; true equilibrium was not achieved even after almost two years of reaction time.

We determined that the steady-state dissolved plutonium concentrations ranged from $2 \times 10^{-7}$ to $8 \times 10^{-7}$ moles per liter for the $\mathrm{H}-17$ Brine experiments started with initially $\mathrm{Pu}(\mathrm{III}), \mathrm{Pu}(\mathrm{IV}), \mathrm{Pu}(\mathrm{V})$, and $\mathrm{Pu}(\mathrm{VI})$. The steady-state dissolved plutonium concentration in the initially $\mathrm{Pu}(\mathrm{IV})$-polymer experiment was an order of magnitude lower at $3 \times 10^{-8}$ moles per liter.

The oxidation state determinations were conclusive in that we were able to determine the relative amounts of all four of the primary plutonium oxidation states in each of the experiments. We found the dominant oxidation state for the soluble plutonium in all five of the experiments to be $\mathrm{Pu}(\mathrm{VI})(70-90 \%)$. The remainder of the soluble plutonium was composed of mostly $\mathrm{Pu}(\mathrm{V})$ with only traces of $\mathrm{Pu}(\mathrm{IV})$ and $\mathrm{Pu}(\mathrm{III})$ being present.

As for the solid phases, we found that for the initially $\mathrm{Pu}(\mathrm{IV})$-polymer experiment the steady-state solid appears to be primarily polymeric-plutonium(IV) with a small amount of an unidentified component. The solids produced in the initially $\mathrm{Pu}(\mathrm{III})$ and $\mathrm{Pu}(\mathrm{IV})$ experiments are primarily an unidentified precipitate 
with some polymeric-plutonium(IV). The solids produced in the initially $\mathrm{Pu}(\mathrm{V})$ and $\mathrm{Pu}(\mathrm{VI})$ experiments dissolved easily in acid, effervescing as they dissolved. Both of the powder patterns closely match the published patterns for the potassium and ammonium plutonyl(V) carbonates, but they could only be indexed with a monoclinic crystal lattice, suggesting that these two solids are sodium plutonyl(V) carbonates.

\section{Acknowledgmerits}

This work was performed at the Lawrence Berkeley Laboratory for Sandia National Laboratories under Contract No. 40-2516. The Lawrence Berkeley Laboratory is operated by the University of California for the U.S. Department of Energy under Contract DE-AC-03-76SF00098.

\section{REFERENCES}

1. Novak, C.F. 1992. An Evaluation of Radionuclide Batch Sorption Data on Culebra Dolomite for Aqueous Compositions Relevant to the Human Intrusion Scenario for the Waste Isolation Pilot Plant (WIPP). SAND91-1299. Albuquerque, New Mexico: Sandia National Laboratories.

2. Cohen, D. 1961a. "Electrochemical Studies of Plutonium Ions in Perchloric Acid Solution," Journal of Inorganic and Nuclear Chemistry. Vol. 18, 207-216.

3. Newton, T.W., D.E. Hobart, and P.D. Palmer. 1986. The Preparation and Stability of Pure Oxidation States of Neptunium, Plutonium, and Americium. LAUR-86-967. Los Alamos, NM: Los Alamos National Laboratory. (Copies of paper available from authors).

4. Cohen, D. 1961b. "The Absorption Spectra of Plutonium Ions in Perchloric Acid Solution," Journal of Inorganic and Nuclear Chemistry. Vol. 18, 211-218.

5. Nitsche, H., R.C. Gatti, and S.C. Lee. Unpublished. "Low-level Determination of Plutonium by Gamma and L-X-ray Spectroscopy," Proceedings of International Topical Conference on Methods and Applications of Radioanalytical Chemistry-II, Kona, HI, April 21-27, 1991.

6. Nitsche, H., S.C. Lee, and R.C. Gatti. 1988. "Determination of Plutonium Oxidation States at Trace Levels Pertinent to Nuclear Waste Disposal," Journal of Radioanalytical and Nuclear Chemistry. Vol. 124, no. 1, 171-185.

7. Zolotov, Y.A., Chmutova, M.K., and Palei, P.N.: Zh. Anal. Khim. 21, 1217 (1966) 
8. Garrels, R.M. 1960. Mineral Equilibria at Low Temperature and Pressure. New York: Harper and Brothers.

9. Langmuir, D. 1971. "Eh-pH Determination," Procedures in Sedimentary Petrology. Ed. R. E. Carver. New York: Wiley-Interscience. 597-635.

10. Silver, G.L. 1972. "Suggestion for the Determination of Plutonium Valencies in Aqueous Solutions," Radiochemistry and Radioanalytical Letters. Vol. 9, nos. $5-6,315-320$.

11. Mooney, R.C.L. and Zachariasen, W.H.: 1949. "Crystal Structure Studies of Oxides of Plutonium," The Transuranium Elements. Research Papers. Eds. G.T. Seaborg, J.J. Katz, and W.M. Manning. New York: McGraw-Hill. Part II, 1442-1447.

12. Bagnall, K.W., and J.B. Laidler. 1964. "Neptunium and Plutonium Trioxide Hydrates," Journal of the Chemical Society. August 1964, 2693-2696.

13. Ellinger, F.H. and Zachariasen, W. H.: J. Phys. Chem. 58, 405 (1954).

14. Navratil, J.D., and H.L. Bramlet. 1973. "Preparation and Characterization of Plutonyl(VI) Carbonate," Journal of Inorganic and Nuclear Chemistry. Vol. 35, no. 1, 157-163.

15. Nigon, J.P., Penneman, R.A., Staritzky, E., Keenan, T.K., and Asprey, L.B.: J. Phys. Chem. 58, 403 (1954) 
Table 1. Composition of $\mathrm{H}-17$ Brine.

\begin{tabular}{|c|c|c|c|}
\hline & Molarity & $\mathrm{g} / \mathrm{L}$ & ppm \\
\hline $\mathrm{Ca}^{2+}$ & 0.0289 & 1.159 & 1159 \\
\hline $\mathrm{Mg}^{2+}$ & 0.0741 & 1.800 & 1800 \\
\hline $\mathrm{Na}^{+}$ & 2.397 & 55.113 & 55113 \\
\hline $\mathrm{K}^{+}$ & 0.0307 & 1.200 & 1200 \\
\hline $\mathrm{Cl}^{-}$ & 2.482 & 88.000 & 88000 \\
\hline $\mathrm{SO}_{4}{ }^{2-}$ & 0.0750 & 7.200 & 7200 \\
\hline $\mathrm{Br}^{-}$ & 0.00095 & 0.043 & 43 \\
\hline $\mathrm{B}^{3+}$ & 0.00398 & 0.076 & 76 \\
\hline $\begin{array}{l}\text { Total Inorganic Carbon (TIC), } \\
\quad \text { as } \mathrm{HCO}_{3} \\
\mathrm{pH}=7.0\end{array}$ & 0.00082 & 0.050 & 50 \\
\hline $\begin{array}{l}\left.\mathrm{pCO}_{2(\mathrm{~g})}=10^{-2.56} \mathrm{ATM}\right) \\
\text { lonic Strength }=3.0 \mathrm{molal} \\
\text { Density }=1.10 \mathrm{~g} / \mathrm{cm}^{3}\end{array}$ & & & \\
\hline
\end{tabular}

Table 2. Steady-state solution $\mathrm{pH}$ values, plutonium concentrations, and Eh values in $\mathrm{H}-17$ Brine at $25^{\circ} \mathrm{C}$.

\begin{tabular}{lccc}
\hline $\begin{array}{c}\text { Initial Oxidation } \\
\text { State }\end{array}$ & $\mathrm{pH}$ & Concentration (M) & $\begin{array}{c}\text { Eh (mV) vs. normal } \\
\text { hydrogen electrode }\end{array}$ \\
\hline $\mathrm{Pu}(\mathrm{IV})$-polymer & $7.15 \pm 0.05$ & $(2.97 \pm 1.02) \times 10^{-8}$ & $471 \pm 15$ \\
$\mathrm{Pu}(\mathrm{III})$ & $7.09 \pm 0.06$ & $(1.63 \pm 0.52) \times 10^{-7}$ & $435 \pm 15$ \\
$\mathrm{Pu}(\mathrm{IV})$ & $7.13 \pm 0.04$ & $(1.78 \pm 0.39) \times 10^{-7}$ & $490 \pm 15$ \\
$\mathrm{Pu}(\mathrm{V})$ & $7.09 \pm 0.08$ & $(3.66 \pm 0.85) \times 10^{-7}$ & $394 \pm 15$ \\
$\mathrm{Pu}(\mathrm{VI})$ & $7.08 \pm 0.09$ & $(-\cdot .64 \pm 2.31) \times 10^{-7}$ & $404 \pm 15$ \\
\hline
\end{tabular}


Table 3. Methods Used for Determining Plutonium Oxidation States in H-17 Brine.

\begin{tabular}{|c|c|c|}
\hline \multirow[t]{2}{*}{ Method } & \multicolumn{2}{|c|}{ Oxidation State Distribution } \\
\hline & Organic Phase & Aqueous Phase \\
\hline $\begin{array}{l}\text { PMBP Extraction at } \\
\mathrm{pH}=0\end{array}$ & $(+4)$ & $(+3,+5,+6, p)^{a}$ \\
\hline $\begin{array}{l}\text { PMBP Extraction at } \\
\mathrm{pH}=0 \mathrm{w} / \mathrm{Cr}_{2} \mathrm{O}_{7}^{=}\end{array}$ & $(+3,+4)$ & $(+5,+6, p)^{a}$ \\
\hline $\begin{array}{l}\text { HDEHP Extraction } \\
\text { at } \mathrm{pH}=0\end{array}$ & $(+4,+6)$ & $(+3,+5, p)^{a}$ \\
\hline $\begin{array}{l}\text { HDEHP Extraction } \\
\text { at } \mathrm{pH}=0 \mathrm{w} / \mathrm{Cr}_{2} \mathrm{O}_{7}^{=}\end{array}$ & $(+3,+4,+5,+6)$ & $(p)^{a}$ \\
\hline
\end{tabular}


Table 4. X-ray powder diffraction patterns for the unwashed solids obtained in the plutonium $/ \mathrm{H}-17$ oversaturation experiments.

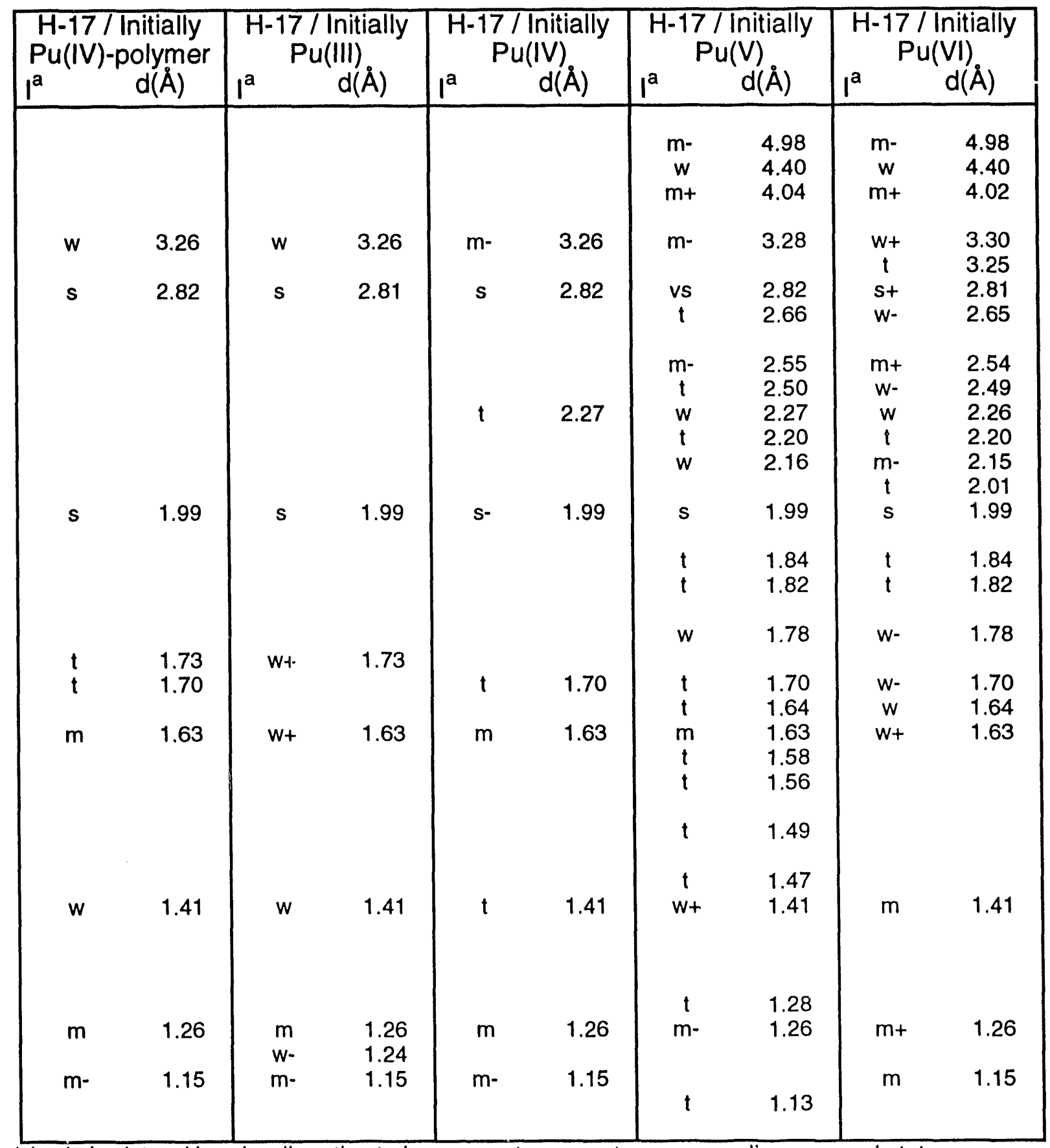

(a) relative intensities visually estimated: $v s=$ very strong, $s=$ strong, $m=$ medium, $w=w e a k, t=$ trace. 


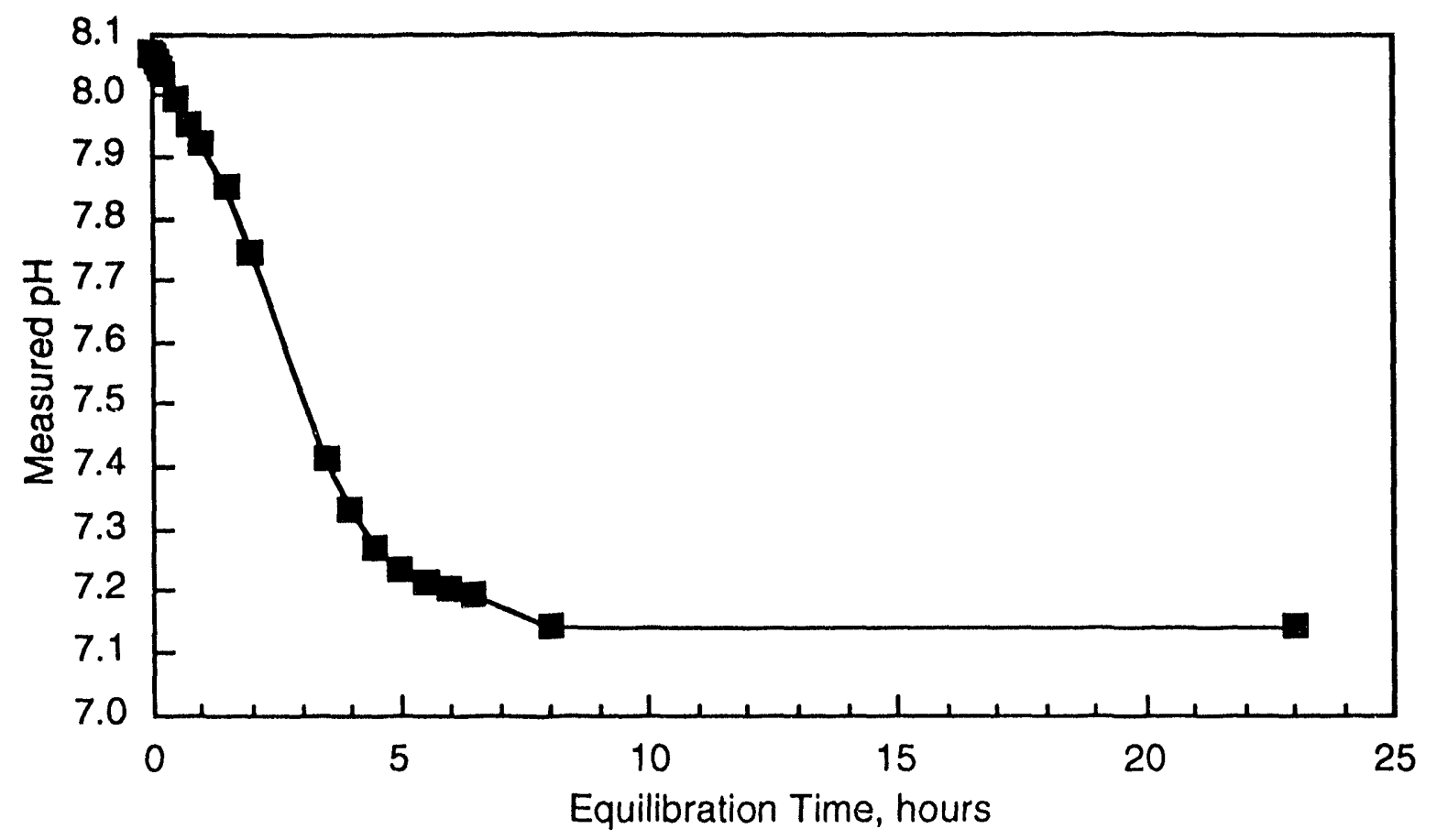

Figure 1. The operational $\mathrm{pH}$ measured by glass electrode in $\mathrm{H}-17$ Brine during saturation with a gas mixture of $2634 \pm 91 \mathrm{ppm} \mathrm{CO} 2,20.75 \pm 0.88$ percent $\mathrm{O}_{2}$, with the balance made up of $\mathrm{Ar}$. 


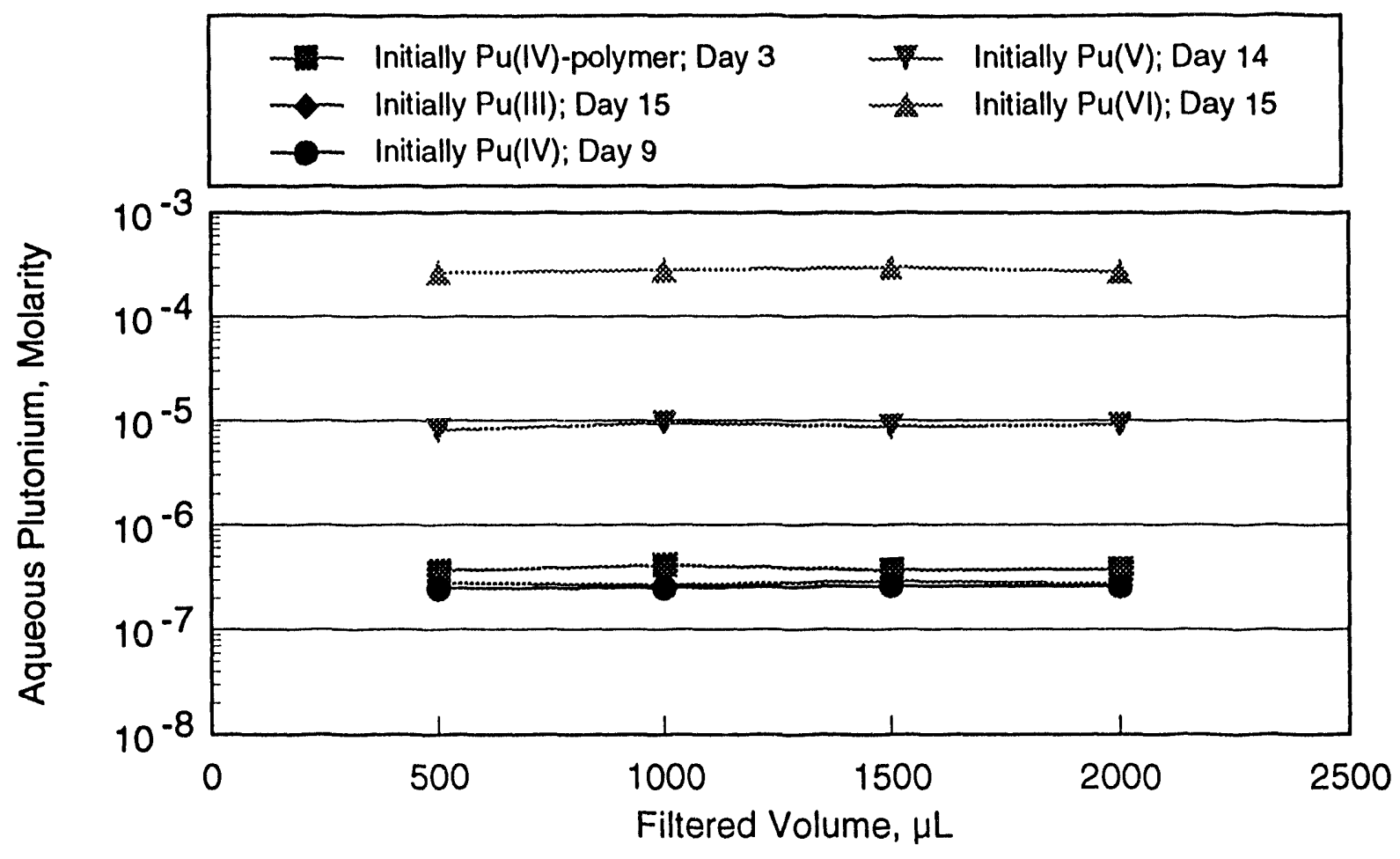

Figure 2. Results of filtration experiments with Centricon-30 filters. The lack of change in concentrations indicates there was no significant retention of plutonium on the filters upon initiating the experiments. 


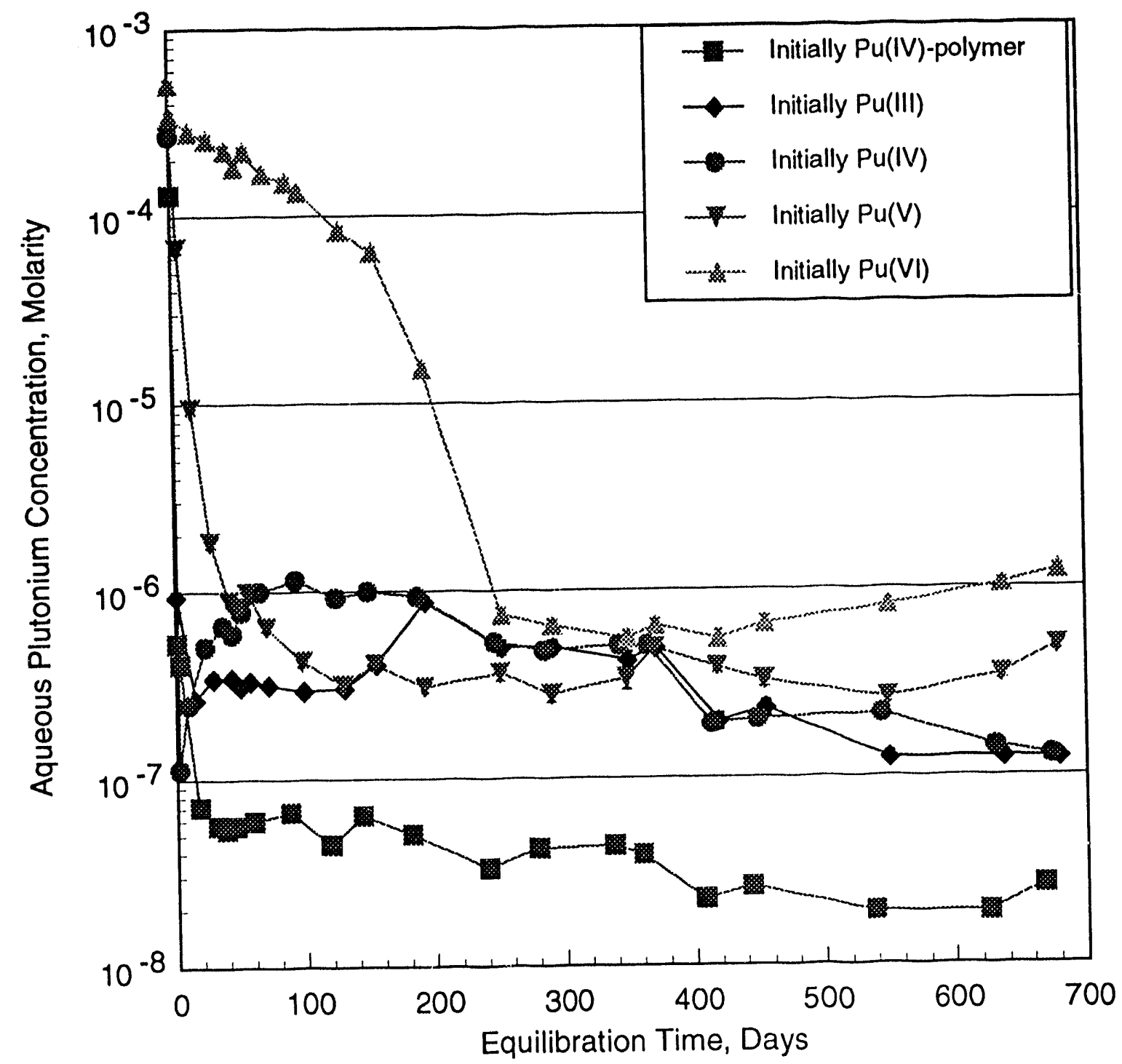

Figure 3. Total dissolved plutonium concentrations versus time for five initial forms of aqueous plutonium in $\mathrm{H}-17$ Brine. 


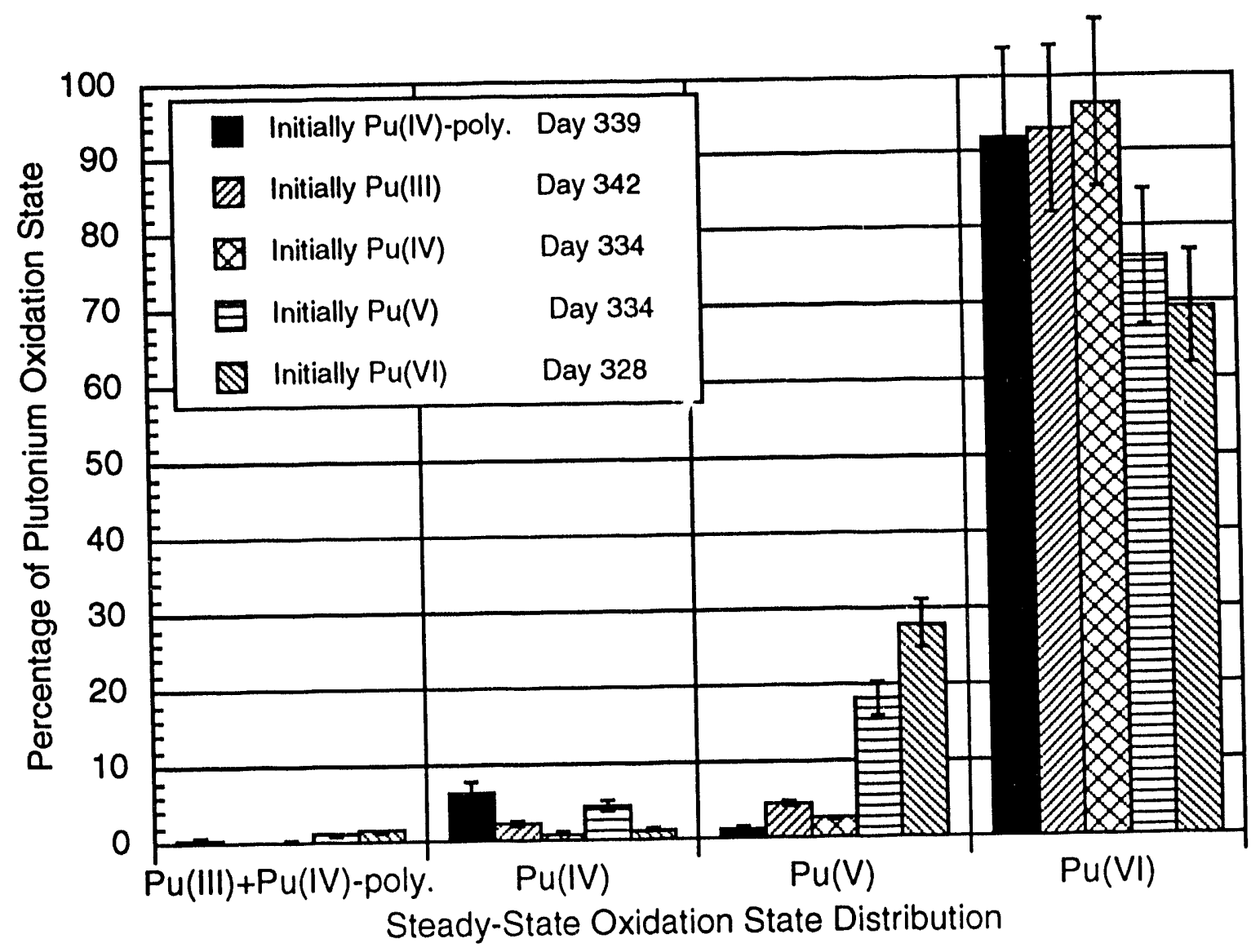

Figure 4. Plutonium oxidation state distributions in five different $\mathrm{H}-17$ Brine experiments at steady-state conditions. 


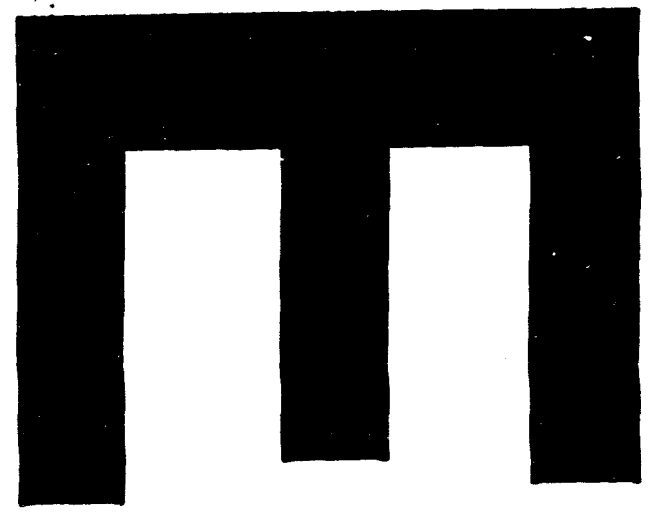

$\omega$
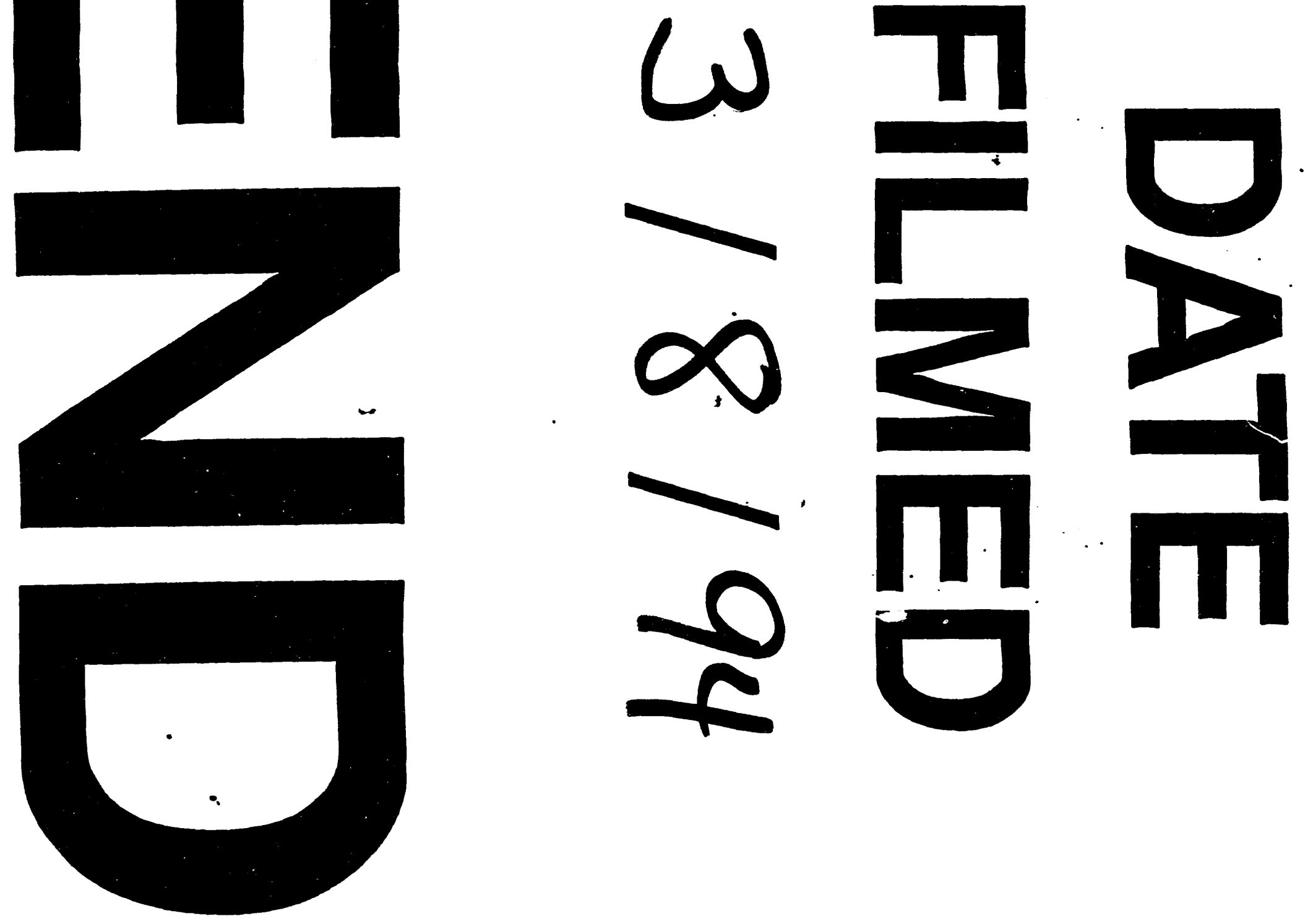
